\title{
KONDISI TREND BIOMASSA IKAN LAYANG (Decapterus spp.) DI LAUT JAWA DAN SEKITARNYA
}

\author{
Duto Nugroho*)
}

\begin{abstract}
ABSTRAK
Ikan layang (Decapterus spp.) adalah salah satu komoditas perikanan pelagis kecil penting di Indonesia. Ikan layang (Decapterus macrosoma dan D. russelli) merupakan komponen utama ikan pelagis kecil di Laut Jawa. Ke-2 jenis ikan tersebut mendominasi hasil tangkapan pukat cincin lebih dari $50 \%$. Perubahan eksploitasi terjadi melalui kapasitas penangkapan (ukuran kapal dan termásuk kekuatan mesin, serta perluasan daerah penangkapan) dan taktik penangkapan (penggunaan cahaya sebagai alat bantu mengumpulkan ikan menggantikan peranan rumpon), telah merubah efisiensi alat tangkap pukat cincin. Hasil penelitian menunjukkan stok (biomassa) ikan layang telah pulih kembali dalam tahun-tahun belakangan ini. Tetapi situasi sebaliknya ditunjukkan oleh hasil tangkapan yang menurun dan peningkatan upaya penangkapan. Berdasarkan pada mortalitas penangkapan dan upaya penangkapan yang disesuaikan kembali melalui $F=q^{\star} E$ membuktikan bahwa pulih stok bersifat palsu. Kenaikan laju mortalitas penangkapan telah menyebabkan penurunan stok ikan layang yang serius.
\end{abstract}

KATA KUNCI: ikan layang, Decapterus spp., penangkapan, Laut Jawa

ABSTRACT: Biomasa trend condition of scads (Decapterus spp.) fishery in the Java Sea and its adjacent waters. By: Duto Nugroho

The scads (Decapterus spp.) are one of the most important species of small pelagic fish in Indonesia. The scads (Decapterus macrosoma and D. russelli) were the main component of small pelagic resources in the Java Sea. These species dominated catch of purse seiner more than $50 \%$. Change in exploitation occurred through the fishing capacity (size of vessel, including main engine, and enlargement of the fishing areas) and the change fishing tactic (spotlight replaced, fish aggregating device), that has led to changes in efficiency of fishing gear. The results indicated that scads stock (biomass) has recovered in recent years. However, the opposite situation was showed by decreasing catch and increasing effort. Based on fishing mortality and effort readjusted through $F=q^{\star} E$ proved that recovery of scads stock was quasi (quasi recovery). The increasing fishing mortality rate has caused serious stock decline.

KEYWORDS: $\quad$ scads, Decapterus spp., fishing, Java Sea

\section{PENDAHULUAN}

Eksploitasi sumber daya ikan pelagis kecil di Laut Jawa mempunyai sejarah panjang. Sumber daya ikan tersebut telah lama dieksploitasi oleh berbagai alat tangkap, salah satunya adalah payang. Payang (danish seine) telah beroperasi di dekat pantai utara Laut Jawa dari Kepulauan Seribu (Jakarta) sampai dengan Kepulauan Kangean di bagian timur Laut Jawa (Rosendaal, 1910). Verloop (1904) mengatakan hasil tangkapan payang yang didaratkan di sepanjang pantai utara Jawa mencapai sekitar 28.000 ton. Pada 1909, hasil tangkapan alat ini di sekitar Kepulauan Kangean sekitar 9.000 ton, terutama jenis ikan layang (Decapterus spp.) (Kampen, 1922). Di Laut Jawa, paling sedikit terdapat 2 jenis ikan layang (Decapterus russelli dan Decapterus macrosoma). Ke-2 jenis ikan layang tersebut merupakan komponen utama di perairan ini, dominasi jenis ikan ini terjadi pada daerah penangkapan yang dipengaruhi oleh massa air bersifat oseanik. Potier \& Sadhotomo (1995) menyimpulkan bahwa ikan layang jenis $D$. macrosoma lebih bersifat oseanik daripada ikan layang jenis $D$. russelli. Sebelum pukat cincin beroperasi di Laut Jawa, ikan layang jenis $D$. russelli merupakan proporsi terbesar dari kategori ikan layang (Decapterus spp.). Interaksi antara $D$. russelli dan $D$. macrosoma terjadi di perairan bagian timur Laut Jawa dan bagian barat Selat Makassar, di mana D. macrosoma mendominasi hasil tangkapan pada bulan Oktober sampai dengan April, setelah itu digantikan oleh kenaikan hasil tangkapan D.russelli (Atmaja, 1999).

Sejak tahun 1970-an, perkembangan eksploitasi sumber daya ikan pelagis kecil di Laut Jawa sangat erat kaitan dengan perkembangan alat tangkap pukat cincin. Setelah pasca pelarangan pukat 
harimau tahun 1980 , alat tangkap ini menjadi semi industri dan berkembang cepat, baik kapasitas penangkapan (ukuran kapal dan termasuk kekuatan mesin) dan perluasan daerah penangkapan, maupun peningkatan efisiensi penangkapan melalui penggunaan jumlah lampu sorot (cahaya) yang cenderung meningkat.

Beberapa peneliti telah mendiskusikan eksploitasi sumber daya ikan layang (Decapterus spp.) di Laut Jawa (Sadhotomo et al., 1983; Atmaja, 1988; Widodo, 1988; Potier, 1998; Sadhotomo, 1998). Pada umumnya berkesimpulan berbeda. Indeks laju eksploitasi untuk $D$. macrosoma dan $D$. russelli telah mengalami penangkapan yang berlebihan $(E>0,5)$ (Sadhotomo et al., 1983; Atmaja, 1988). Widodo (1988) menyimpulkan bahwa tingkat pengusahaan stok $D$. russelli di bawah tingkat optimal, sedangkan $D$. macrosoma telah mengalami penangkapan yang berlebihan. Potier (1998) mengatakan bahwa nilai indeks laju eksploitasi untuk $D$. macrosoma dan $D$. russelli $(E<0,5)$ dan $E_{0,1}$ berkisar antara 0,41 sampai dengan 0,42. Sadhotomo (1998) mengajukan pertanyaan tentang kesimpulan berbeda tersebut apakah kondisi tingkat eksploitasi kurun waktu tahun 1993 sampai dengan 1995 lebih rendah daripada tahun-tahun sebelum (tahun 1981 sampai dengan 1982 dan tahun 1986 sampai dengan 1987). Pada kenyataan, ekspansi kapasitas kapal dan taktik penangkapan dimulai pada tahun 1986 sampai dengan 1987.

Dari pengamatan aspek reproduksi telah diketahui bahwa ke-2 jenis ikan layang ini mempunyai pola reproduksi yang berbeda. $D$. russelli yang tertangkap adalah ikan yang belum matang gonad dan ikan yang salin, sedangkan $D$. macrosoma sebagian besar didominasi oleh ikan yang reproduktif tidak aktif. Sangat sedikit contoh yang matang gonad memberi indikasi bahwa tertangkap ikan matang gonad tidak dalam bentuk gelombolan (Atmaja et al., 1995; Atmaja, 1999; Atmaja \& Sadhotomo, 2000). Dari pengamatan genetik disimpulkan bahwa $D$. russelli menyebar luas di paparan Sunda (Perrin, 1998), sedangkan $D$. macrosoma terdiri atas 2 populasi, yaitu populasi Laut Cina Selatan dan populasi Laut Jawa yang menyebar dari bagian timur Laut Jawa sampai dengan Selat Makassar dan bagian utara Sulawesi (Arnaud, 1998).

Aplikasi model produksi surplus pada perikanan multi species didasarkan pada konsiep sistem unit tunggal dari gabungan beberapa spesies yang mempunyai karakteristik biologi sama dan tidak ada hubungan pemangsa-mangsa. Ikan layang sebagai komponen utama (key species) sumber daya ikan pelagis kecil memenuhi asumsi tersebut. Penelitian ini bertujuan untuk mengetahui status ikan layang berdasarkan pada variasi model produksi surplus, yaitu dinamika biomasa dan mortalitas penangkapan.

\section{BAHAN DAN METODE}

Ikan-ikan pelagis kecil di Laut Jawa ditangkap dengan menggunakan berbagai jenis alat tangkap baik di perairan pantai maupun di perairan lepas pantai, di mana sebagian besar produksi berasal dari armada perikanan pukat cincin. Kelompok jenis ikan layang (Decapterus spp.) merupakan komponen utama di perairan ini. Untuk alasan ini diasumsikan bahwa hasil tangkapan berasal dari populasi sama.

Sumber data berasal dari kapal pukat cincin komersial yang berpangkalan di Pekalongan dan Juwana, yaitu data berupa hasil tangkapan dan upaya penangkapan selama kurun waktu tahun 1976 sampai dengan 2004. Rata-rata produksi ikan layang tersebut dibandingkan dengan produksi ikan layang seluruh Laut Jawa dari statistik perikanan Indonesia hanya mewakjili sekitar $40 \%$. Hal ini, disebabkan berlawanannya trend, di mana trend produksi ikan layang dari statistik perikanan Indonesia cenderung terus meningkat, sedangkan produksi ikan layang dari pukat cincin telah menurun drastis (Lampiran 1).

Dalam kajian stok ikan, laju pertumbuhan stok (produksi surplus) dapat digambarkan sebagai fungsi logistik atau fungsi gompertz, yaitu:

Fungsi logistik:

$F(B)=r B_{t}\left(1-B_{t} / K\right)$

Fungsi gompertz:

$F(B)=r B_{t} \operatorname{Ln}\left(K / B_{t}\right)$

Perubahan stok ikan per waktu akibat penangkapan adalah selisih antara laju pertumbuhan stok dikurangi dengan hasil tangkapan (C) secara matematik dapat ditulis:

$$
\partial \mathrm{B} / \partial \mathrm{t}=\mathrm{F}(\mathrm{B})-\mathrm{C} \text { atau } \Delta \mathrm{B} / \Delta \mathrm{t}=\mathrm{F}(\mathrm{B})-\mathrm{C}
$$

Jika $\Delta t=1$ tahun maka persamaan (3) dapat ditulis:

$$
B_{t+1}=B_{t}+F(B)-C
$$

Hasil tangkapan ditentukan oleh upaya penangkapan dengan berpatokan bahwa 
mortalitas penangkapan sebanding upaya penangkapan, yaitu:

$$
F=q^{*} E, C=q B E \text { atau } C / B=q^{*} E
$$

Hasil tangkapan lestari dihitung berdasarkan pada fungsi logistik berikut:

$$
\begin{aligned}
& C=\alpha E-\beta^{*} E^{2} \text {, di mana } \alpha=q K \text { dan } \beta=q^{2} K / r \ldots \ldots . .(6 \\
& E_{M S Y}=\alpha / 2{ }^{*} \beta=r / 2 q, C_{M S Y}=\alpha^{2} / 4^{*} \beta=r K / 4 \\
& F_{M S Y}=r / 2 \text { dan } B_{M S Y}=K / 2=2 C_{M S Y} / r \\
& \text { Fungsi gompertz: } \\
& C=q K E{ }^{*} E X P-\left(q / r^{*} E\right) \ldots \ldots \ldots \ldots \ldots \ldots \ldots \ldots \ldots \ldots \ldots \\
& E_{M S Y}=r / q, C_{M S Y}=r^{*} K^{*} E X P(-1) \\
& F_{M S Y}=r \text { dan } B_{M S Y}=K^{*} E X P(-1)=C_{M S Y} / r
\end{aligned}
$$

Nilai parameter biologi $\mathrm{K}$ (enviromental carrying capacity), q (koefisien daya tangkap), dan $r$ (laju pertumbuhan intrinsik) diduga melalui fungsi gompertz dan fungsi logistik, sebagai berikut:

Fungsi gompertz menggunakan prosedur (Clarke, et al., 1992):

$$
\begin{aligned}
& \operatorname{Ln}\left(U_{t+1}\right)=2 r /(2+r) \quad \operatorname{Ln}(q K)+(2-r) /(2+r) \ln \quad\left(U_{t}\right)- \\
& q /(2+r)\left(E_{t}+E_{t+1}\right)
\end{aligned}
$$

atau $Y=\beta_{0}+\beta_{1} X_{1}-\beta_{2} X_{2}$

Fungsi logistik menggunakan prosedur Walters \& Hilborn (1976) diacu dalam Hilborn \& Walters (1992):

$$
\begin{aligned}
& \left(U_{t+1} / U_{t}\right)-1=r-r /\left(q^{*} K\right) U_{t}-q E_{t} \\
& \text { atau } Y=\beta_{0} \beta_{1} X_{1}-\beta_{2} X_{2}
\end{aligned}
$$

di mana:

$$
\begin{aligned}
& C=\text { hasil tangkapan } \\
& q=\text { koefisien kemampuan tangkap } \\
& E=\text { upaya penangkapan } \\
& B=\text { biomassa } \\
& F=\text { mortalitas penangkapan } \\
& U=\text { hasil tangkapan per upaya penangkapan } \\
& \quad \text { (catch per unit of effort) } \\
& r=\text { laju pertumbuhan intrinsik }
\end{aligned}
$$

\section{HASIL DAN BAHASAN}

\section{Perkembangan Produksi Ikan Layang (Decapterus spp.) dan Upaya Penangkapan}

Perkembangan alat tangkap pukat cincin di pantai utara Jawa, sejalan dengan dinamika perikanan yang dicirikan oleh ekspansi kapasitas kapal (ukuran kapal dan termasuk kekuatan mesin, serta perluasan daerah penangkapan), perluasan daerah dan perubahan taktik penangkapan (penggunaan cahaya sebagai alat bantu pengumpul ikan menggantikan peranan rumpon), telah merubah efisiensi alat tangkap pukat cincin. Berdasarkan pada Gambar 1b dapat dilihat bahwa jumlah hari operasi penangkapan (E) cenderung terus meningkat.

Seiring dengan dinamika perikanan pukat cincin, produksi ikan layang terus meningkat dengan puncak pada tahun 1985 mencapai sekitar 54.000 ton atau 107.000 ton berdasarkan pada statistik perikanan, kemudian menurun sangat tajam mencapai 21.000 ton pada tahun 1988. Sejak tahun 1989, produksi ikan layang meningkat kembali dan mencapai pucak produksi pada tahun 1995. Berdasarkan pada statistik perikanan Indonesia, sejak tahun 1988 sampai dengan 1997 trend produksi cenderung terus meningkat. Sadhotomo (1998) mengatakan bahwa produksi ikan berdasarkan pada statistik perikanan Indonesia cenderung meningkat sekitar 4 sampai dengan $10 \%$ per tahun, apapun kondisi perikanan. Direktorat Jenderal Perikanan Tangkap (2004) memperlihatkan perkembangan produksi perikanan ikan laut meningkat rata-rata $5,4 \%$ selama kurun waktu tahun 2001 sampai dengan 2003. Sebaliknya realitis perikanan memperlihatkan bahwa produksi ikan layang yang berasal dari perikanan pukat cincin cenderung terus menurun (Gambar 1a). Sebelum ekspansi daerah penangkapan ikan layang (D. russelli) merupakan proporsi tebesar $(>70 \%)$ dari ke-2 jenis ikan layang $(D$. russelli dan $D$. macrosoma) yang tertangkap di Laut Jawa dan sekitar (Gambar 1b).

\section{Laju Pertumbuhan Fungsi Logistik vs Gompertz}

Perubahan kelimpahan stok ikan dipengaruhi 3 parameter dari produksi surplus, yaitu pertumbuhan intrinsik $(r)$, carring capacity (K), koefisien kemampuan tangkap (q), ke-3 parameter ini sangat menentukan besaran stok ikan dan hasil tangkapan. Pendugaan parameter produksi surplus yang diperoleh dari ke-2 metode (laju pertumbuhan logistik Walters \& Hilborn, 1976 dan pertumbuhan gompertz Clarke, Yoshimoto \& Pooley, 1992) diterakan pada Tabel 1 dan Gambar 2.

\section{Dinamika Perilaku Biomassa}

Sejauh tidak terjadi perubahan faktor lingkungan, seperti kegagalan peremajaan akibat anomali klimatologi, bencana alam, dan polusi yang menyapu sebagian besar populasi ikan. Perubahan stok ikan hanya dipengaruhi oleh hasil tangkapan, maka bagaimana hasil tangkapanmempengaruhi populasi ikan dapat dihitung secara 

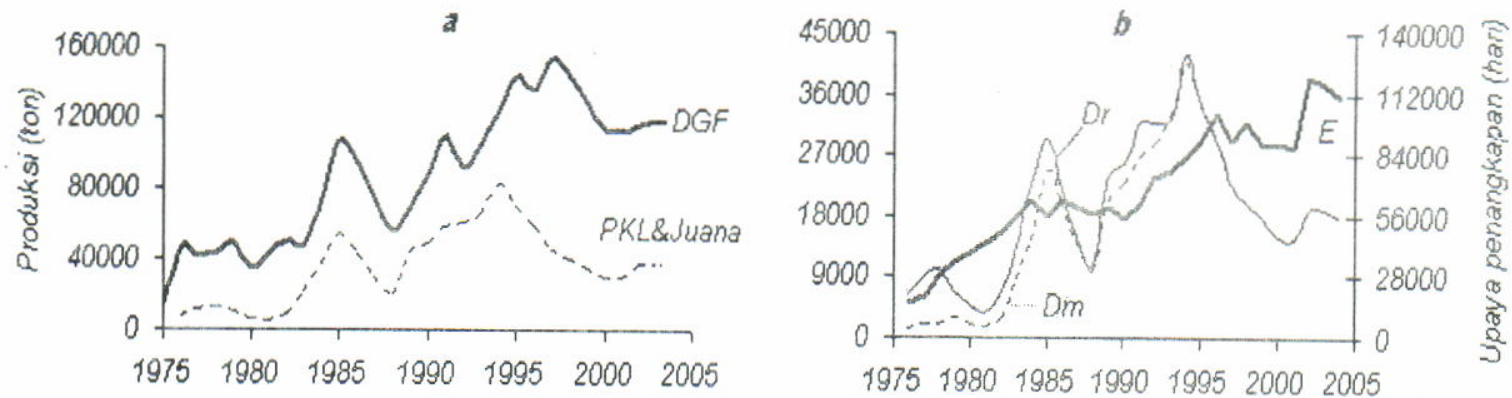

Tahun

Gambar 1. Produksi ikan layang (D. russelli dan D. macrosoma) dan upaya penangkapan pukat cincin. Keterangan: $\mathrm{CPKL}+$ Juwana $=$ produksi ikan layang dari tempat pendaratan ikan Pekalongan dan Juwana; Statistik DGF = statistik perikanan Indonesia; $\mathrm{Dr}=\mathrm{D}$. russelli; $\mathrm{Dm}=\mathrm{D}$. macrosoma; $\mathrm{E}=$ upaya

Figure 1. Production of scads (D. russelli and D. macrosoma) and effort of purse seine

Remarks: CPKL+Juwana $=$ Production of scads at Pekalongan and Juwana Landing Place; Statistik DGF = fisheries statistics of Indonesia; $D r=D$. russelli; $D m=D$. macrosoma; $E=$ effort, day

Tabel 1. Parameter fungsi produksi surplus dari model logistik dan gompertz berdasarkan pada sumber data Pekalongan dan Juwana

Table 1. Parameters of surplus production function from logistic and gompertz model based on source data Pekalongan and Juwana

\begin{tabular}{lcccccc} 
& \multicolumn{4}{c}{ Logistik } & \multicolumn{3}{c}{ Gompertz. } \\
\cline { 2 - 7 } \multicolumn{1}{c}{ Parameter } & Dm & D r & Decapterus spp. & Dm & D r & Decapterus spp. \\
\hline $\mathrm{r}$ & 0,62 & 0,7 & 0,97 & 0,46 & 0,41 & 0,52 \\
$\mathrm{~K}(\times 1000$ ton $)$ & 174,3 & 165,8 & 228 & 141,1 & 176 & 262,2 \\
$\mathrm{q}\left(\times 10^{-5}\right)$ & 0,42 & 0,51 & 0,68 & 0,89 & 0,91 & 1,05 \\
$\mathrm{E}_{\text {MSY }}(\times 1000$ hari) & 73,2 & 68,6 & 70,9 & 51,2 & 45,1 & 49,4 \\
$\mathrm{C}_{\text {MSY }}(\times 1000$ ton $)$ & 26,8 & 29,7 & 55,3 & 23,8 & 26,5 & 50 \\
B $_{\text {MSY }} \times 1000$ ton $)$ & 87 & 82,9 & 114 & 51,9 & 64,7 & 96,5 \\
F $_{\text {MSY }}$ & 0,31 & 0,35 & 0,48 & 0,23 & 0,41 & 0,52 \\
\hline
\end{tabular}

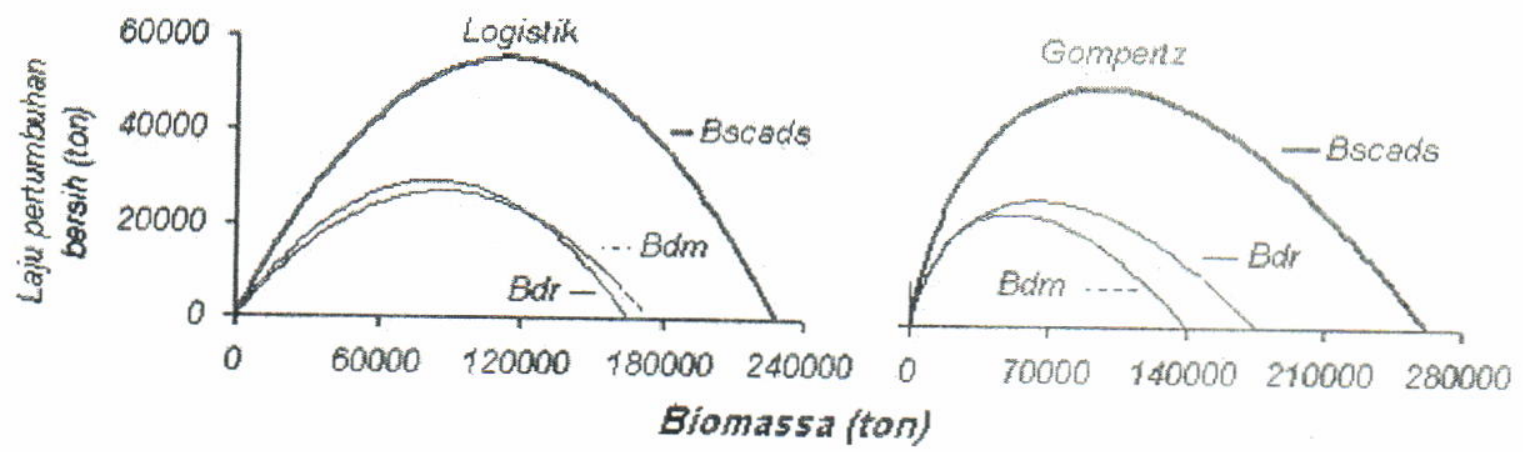

Gambar 2. Kurva pertumbuhan bersih stok ikan layang (Decapterus spp.).

Keterangan: Bscads $=$ Decapterus spp.; $\mathrm{Bdm}=D$. macrosoma; dan Bdr $=D$. russelli

Net growth of scads stocks (Decapterus spp.).

Remarks: Bscads = Decapterus spp.; $B d m=D$. macrosoma; and $B d r=$ D. russelli

matematik, yang ditunjukkan oleh perubahan biomassa (Gambar 3). Biomassa ikan layang cenderung meningkat selama 5 tahun terakhir ini karena produksi surplus lebih besar dari hasil tangkapan, sehingga penurunan mortalitas penangkapan (F1) (Gambar 4a).
Secara teoritis, peningkatan biomassa ikan layang harus diikuti dengan kenaikan hasil tangkapan per satuan upaya. Situasi perikanan pukat cincin saat ini memperlihatkan hasil tangkapan terus menurun dan rata-rata hari operasi penangkapan terus naik, walaupun 


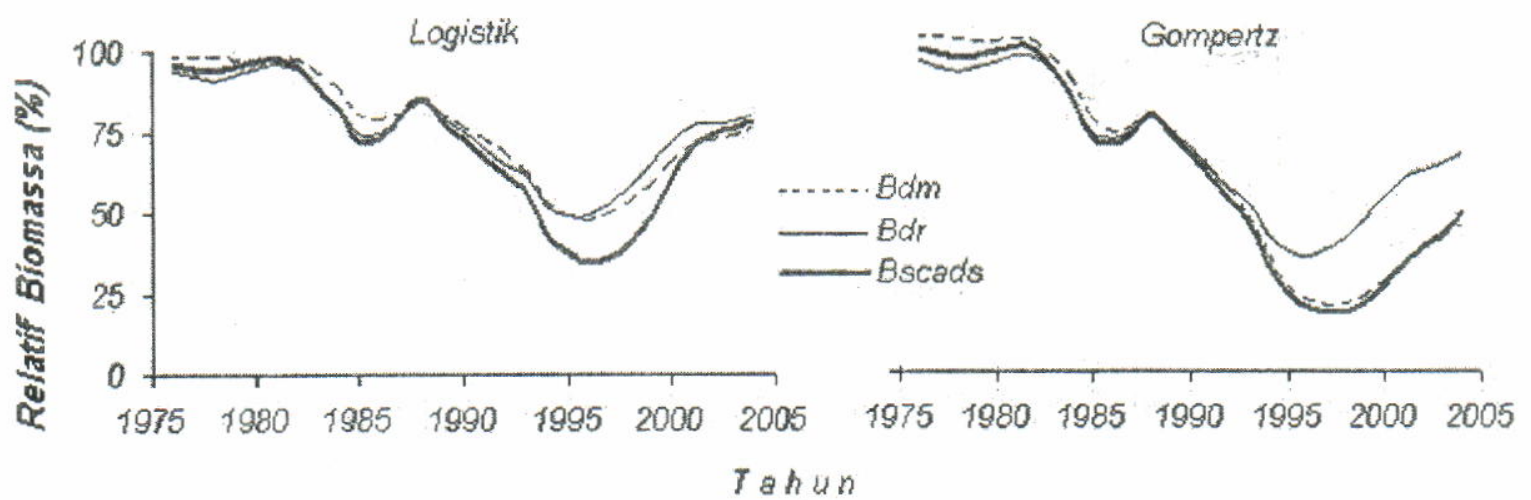

Gambar 3. Dinamika biomassa ikan layang (\%).

Figure 3. Dynamics of scads biomass (\%).

Remarks: Bdm = biomass of D. macrosoma; $B d r=$ biomass of $D$. russelli; $B s c a d s=$ biomass of $D$. macrosoma and $D$. russelli
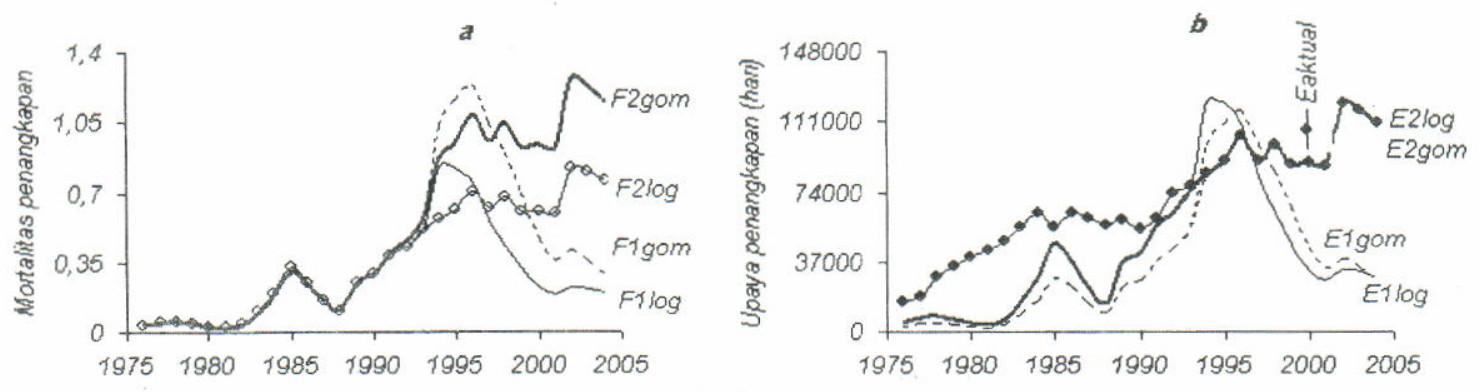

Tahun

Gambar 4. Mortalitas penangkapan ikan layang (Decapterus spp.) setelah $\mathrm{F}_{\mathrm{MSY}}$ diboboti dengan $F=q^{\star} E, F 1$ (sebelum) dan F2 (sesudah), serta perbandingan upaya penangkapan aktual (Eaktual) dengan upaya penangkapan E1 (sebelum) dan E2 (sesudah), gom=Gompertz, log=Logistik.

Figure 4. Fishing mortality of scads (Decapterus spp.) after $F_{M S Y}$ weighted by $F=q^{\star} E, F 1$ (before) and F2 (after), and comparation actual effort with effort before and after weighted by $F=q^{*} E$, gom $=$ Gompertz, log $=$ Logistik.

kemampuan tangkap cenderung meningkat. Hal ini, menunjukkan nelayan semakin sulit mencari gelombolan ikan. Dari kenyataan tersebut menunjukkan kondisi biomassa ikan layang berlanjut menurun atau pulih stok bersifat semu (quasi recovery).

Dengan nilai koefisien kemampuan tangkap (q) konstan diperoleh upaya penangkapan (E1) yang menurun (Gambar 4b), jika upaya penangkapan (eaktual) tetap, maka yang berubah adalah nilai q, dengan slope setelah $\mathrm{F}_{\mathrm{MSY}}$ adalah negatif. Dengan slope q negatif dan E1 lebih kecil daripada Eaktual menunjukkan ketidaksesuaian dengan asumsi awal bahwa mortalitas penangkapan (F) proposional dengan upaya penangkapan (E). Berdasarkan pada mortalitas penangkapan dan upaya penangkapan yang telah diboboti koefisien kemampuan tangkap. Mortalitas penangkapan ikan layang (Decapterus spp.) setelah $\mathrm{F}_{\text {MSY }}$ disesuaikan kembali dengan persamaan (5), maka diperoleh nilai F2 yang cenderung meningkat (Gambar 4a). Selanjutnya, upaya penangkapan (E2) dihitung dari F2 dengan koefisien kemampuan tangkap (q) dari Tabel 1. Dengan cara ini diperoleh nilai E2 berimpitan dengan Eaktual, kecuali sebelum $\mathrm{F}_{\mathrm{MSY}}$ upaya penangkapan E2 (tahun 1976 sampai dengan 1993) lebih kecil daripada Eaktual (Gambar 4b). Dengan kenaikan mortalitas penangkapan (F2) tersebut mengakibatkan biomassa turun drastis mencapai kurang dari $25 \%$ dari biomassa awal (Gambar 5).

Pada Gambar 6 dapat dilihat kontradiktif antara hasil tangkapan lestari (Cles1)' yang dihitung dari upaya penangkapan aktual dengan hasil tangkapan aktual pada perkembangan awal perikanan pukat cincin dan pada saat hasil tangkapan menurun, di mana hasil tangkapan aktual di bawah hasil tangkapan lestari. Pada posisi ini dapat diartikan bahwa peningkatan upaya penangkapan belum membahayakan kelestarian 


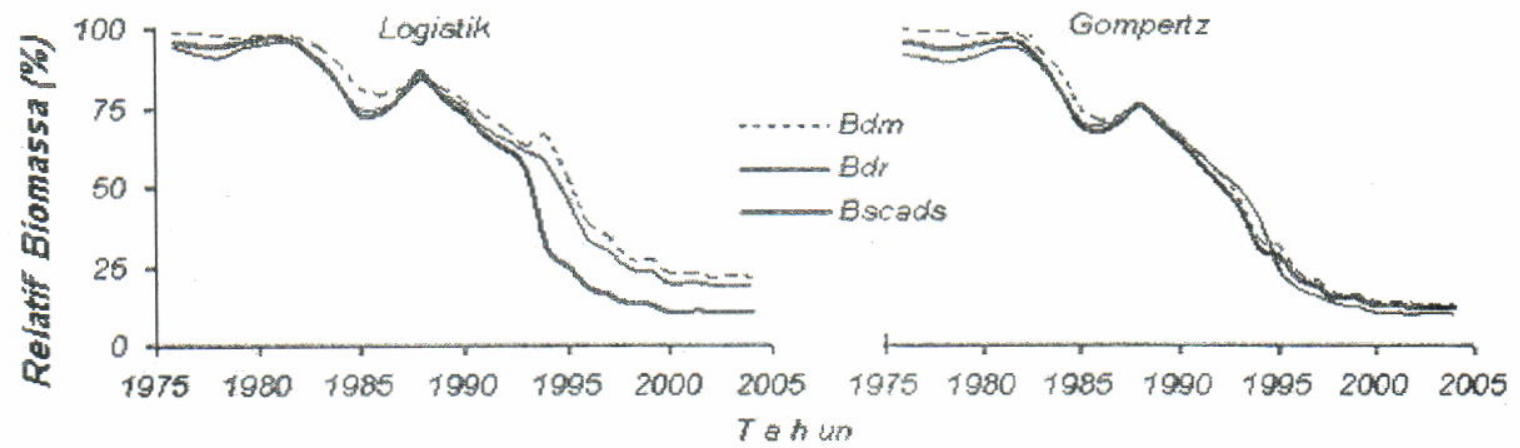

Gambar 5. Dinamika biomassa ikan layang (Decapterus spp.) setelah $F_{M S Y}$ diboboti dengan $F=q^{\star} E$.

Figure 5. Dynamics of scads (Decapterus spp.) after $F_{M S Y}$ weighted by $F=q^{\star} E$.

Remarks: Bdm = biomass of $D$. macrosoma; $B d r=$ biomass of $D$. russelli; $B s c a d s=$ biomass of D. macrosoma and D. russelli
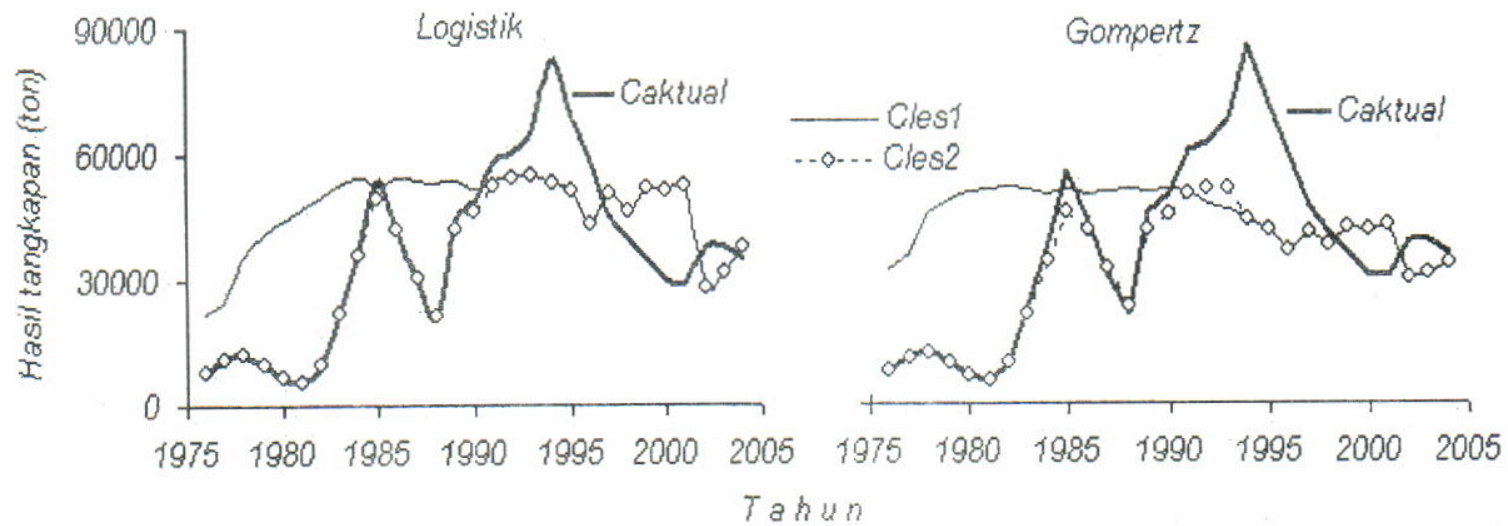

Gambar 6. Perbandingan hasil tangkapan aktual dengan hasil tangkapan lestari ikan layang. Keterangan: Caktual = hasil tangkapan aktual; Cles1 = hasil tangkapan lestari dengan upaya penangkapan aktual; dan Cles2 = hasil tangkapan lestari setelah upaya penangkapan diboboti $F=q^{\star} E$

Figure 6. Comparation of actual catch and sustainable yie/d of scads.

Remarks: Caktual $=$ actual catch; Cles $1=$ sustainable yield of scads after effort weighted by $F=q^{*} E$

sumber daya ikan layang. Sedangkan hasil tangkapan lestari (Cles2) dari upaya penangkapan (E2) menunjukkan tingkat produksi hampir berimpitan dengan hasil tangkapan lestari, kecuali dari tahun 1992 sampai dengan 1997 memperlihatkan hasil tangkapan $\mathrm{di}$ atas hasil tangkapan lestari, kemudian dari tahun 1998 sampai dengan 2001 hasil tangkapan di bawah hasil tangkapan lestari dan selanjutnya hasil tangkapan kembali di atas hasil tangkapan lestari. Dengan demikian, indikasi sangat nyata bahwa setelah tahun 1992, tingkat eksploitasi telah melampaui hasil tangkapan lestari (marginal sustainable yield).

\section{KESIMPULAN DAN SARAN}

Dari hasil penelitian ini dapat ditarik beberapa kesimpulan:

1. Berdasarkan pada mortalitas penangkapan dan upaya penangkapan yang telah diboboti koefisien kemampuan tangkap $\left(F=q^{\star} E\right)$, hasil tangkapan terus menurun dan rata-rata hari operasi penangkapan terus meningkat menunjukkan nelayan semakin sulit mencari gelombolan ikan. Pulih biomassa (stok) ikan layang bersifat semu (quasi recovery).

2. Ekspansi kapasitas kapal (ukuran kapal dan termasuk kekuatan mesin, serta perluasan daerah penangkapan) dan taktik penangkapan telah menyebabkan peningkatan laju mortalitas penangkapan dan penurunan stok ikan layang yang serius.

3. Penurunan stok ikan seyogyanya, direspon melaksanakan tindakan koservasi untuk membangun kembali stok. Solusi jangka pendek melalui regulasi tidak harus membekukan upaya penangkapan dan jumlah kapal yang ada, tetapi membatasi akses kapal baru. Jangka panjang melalui regulasi mengenai peningkatan taktik penangkapan dan mengontrol penggunaan jumlah lampu sorot. 


\section{DAFTAR PUSTAKA}

Arnaud, S. 1998. Le chinchard, Decapterus macrosoma, poisson pélagique de Mer de Java, un exemple d'espèce marine génétiquement structurée. Mem. DEA. USTL-ENSAM. Montpellier. $21 \mathrm{p}$.

Atmaja, S. B. 1988. Estimation of growth and mortality of round scad (Decapterus macrosoma) in the Java Sea, Indonesia. In Venema S, J. M Christensen, \& D. Pauly (Eds): Contribution to Tropical Fisheries Biology: Paper by Participant of FAO/DANIDA Follow-up Training Courses. FAO Fisheries Report 189: 324-345.

-.--. 1999. Variasi geografis hasil tangkapan ikan layang (Decapterus spp.) di perairan bagian selatan Paparan Sunda. Jurnal Penelitian Perikanan Indonesia. Vol.V (3): 63-71.

Atmaja, S. B., B. Sadhotomo, \& Suwarso. 1995. Reproduction of main small pelagic species in Java Sea. In Potier \& S. Nurhakim (Eds.): Biology, Dynamics, and Exploitation of small pelagic in Java Sea. AARD/ORSTOM. 69-84.

Atmaja, S. B. \& B. Sadhotomo. 2000. Variasi geografis hasil tangkapan pukat cincin di bagian selatan Paparan Sunda. Prosiding Seminar Keanekaragaman Hayati Ikan. Pusat Studi IImu Hayati Institut Pertanian Bogor-Pusat Penelitian dan Pengembangan Biologi Lembaga IImu Pengetahuan Indonesia. 221-218.

Clarke, R. P., S. S. Yoshimoto, \& S. G. Pooley. 1992. A bioeconomic analysis of the NorthWestern Hawaiian Islands. Lobster Fishery. Marine Resources Economics. 7 (2): 115-140.

Direktorat Jenderal Perikanan Tangkap. 2004. Pencapaian pembangunan perikanan tangkap tahun 2001 sampai dengan 2003. Departemen Kelautan dan Perikanan. Direktorat Jenderal Perikanan Tangkap. $57 \mathrm{p}$.

Hilborn, R. \& C. J. Walters. 1992. Quantitative fisheries stock assessment: Choice, dynamics, and uncertainty. Chapman and Hall. New York. London. 570 p.
Kampen Van, P. N. 1922. Visscherij en vischteelt in Nederlandsch Indie. H. D. Tjeenk Willink \& Zoon. Harlem. 106 p.

Perrin, C. 1998. Phylogénie de l'ADN mitochondrial, structure géographique et reconstruction de l'histoire évolutive des populations du complexes d'espèce Decapterus cf. russellii dans le sud est asiatique. Mem. DEA. Univ. Mediterranee Aix-Marseille II. 43 p.

Potier, M. \& B. Sadhotomo. 1995. Exploitation of the large and medium seiners fisheries. In Potier \& Nurhakim (Eds.): Biology, Dynamic, and Exploitation. AARD/ORSTOM. 195-214.

Potier, M. 1998. Pêcherie de layang et senneurs semi industriels Javanais: Perspective historique et approche système. Phd Thesis. Université de Montpellier II. 280 p.

Rosendaal Van, A. M., 1910. De layangvisscherij in de Java zee en in Straat Madoera. Mededelingen van het visscherij station te Batavia. Buitenzorg. 5. 21-24.

Sadhotomo, B., S. B. Atmaja, \& S. Nurhakim. 1983. Pendugaan parameter pertumbuhan, indeks kematian, dan yield per rekruit ikan layang, Decapterus maruadsi (Temminck, Schlegel) di Laut Jawa. Jawa. Laporan Penelitian Perikanan Laut. 27: 1-9.

Sadhotomo, B. 1998. Bioécologie des principales espèces pélagiques exploitées en mer de Java. Phd Thesis. Université de Montpellier II. 364 p.

Statistik perikanan Indonesia (Fisheries statistics of Indonesia). 1976-2002. Departemen Pertanian. Direktorat Jenderal Perikanan. Jakarta.

Verloop, G. N. 1904. Het zeevisscherij bedrijf: Haar toestand in 1870 to 1902 , Haar achteruitgang en middelen tot herstel. Tijdschift voor nijverheid en landbouw in Nederlandsch-Indië. 69. 27-33.

Widodo. J. 1988. Dynamic pool analysis of Ikan Layang (Decapterus spp.) in the Java Sea. Jurnal Penelitian Perikanan Laut. No.47: 39-48. 
Lampiran 1. Produksi ikan layang dan upaya penangkapan pukat cincin di Pekalongan dan Juwana, serta produksi ikan layang menurut statistik perikanan Indonesia

Appendix 1. Production of scads (D. russelli and D. macrosoma) and effort of purse seine at Pekalongan and Juwana landing places, and production of scads by fisheries statistics of Indonesia

\begin{tabular}{cccccc}
\hline Tahun & $\begin{array}{c}\text { Upaya penangkapan } \\
\text { (hari) }\end{array}$ & Layang (ton) & $\begin{array}{c}\text { D. russelli } \\
\text { (ton) }\end{array}$ & $\begin{array}{c}\text { D. macrosoma } \\
\text { (ton) }\end{array}$ & $\begin{array}{c}\text { Statistik } \\
\text { DGF (ton) }\end{array}$ \\
\hline 1976 & 15.720 & 7.759 & 6.428 & 1.332 & 46.468 \\
1977 & 18.500 & 11.040 & 9.165 & 1.875 & 40.859 \\
1978 & 28.800 & 12.271 & 10.160 & 2.110 & -44.092 \\
1979 & 35.059 & 9.713 & 6.714 & 2.999 & 48.939 \\
1980 & 39.236 & 6.628 & 4.569 & 2.059 & 34.414 \\
1981 & 43.542 & 5.315 & 3.630 & 1.685 & 42.408 \\
1982 & 48.492 & 9.601 & 6.609 & 2.993 & 50.401 \\
1983 & 55.327 & 22.343 & 13.561 & 8.782 & 47.263 \\
1984 & 63.511 & 37.398 & 22.754 & 14.644 & 73.284 \\
1985 & 55.931 & 53.998 & 29.331 & 24.667 & 106.878 \\
1986 & 63.484 & 42.169 & 22.136 & 20.032 & 94.492 \\
1987 & 60.465 & 29.424 & 15.048 & 14.376 & 74.676 \\
1988 & 56.865 & 20.774 & 10.717 & 10.057 & 55.005 \\
1989 & 59.636 & 44.497 & 24.113 & 20.384 & 67.746 \\
1990 & 54.532 & 48.676 & 25.593 & 23.084 & 87.345 \\
1991 & 60.569 & 58.432 & 31.651 & 26.781 & 109.255 \\
1992 & 73.221 & 60.542 & 31.733 & 28.809 & 91.783 \\
1993 & 76.929 & 65.527 & 32.503 & 33.023 & 104.243 \\
1994 & 83.525 & 82.671 & 42.042 & 40.629 & 124.439 \\
1995 & 90.267 & 69.366 & 34.440 & 34.927 & 143.780 \\
1996 & 103.283 & 58.289 & 29.144 & 29.144 & 135.990 \\
1997 & 90.760 & 45.609 & 22.804 & 22.804 & 153.571 \\
1998 & 99.370 & 39.872 & 19.936 & 19.936 & 143.433 \\
1999 & 88.457 & 35.180 & 17.590 & 17.590 & 128.590 \\
2000 & 89.244 & 29.809 & 14.905 & 14.905 & 113.435 \\
2001 & 87.240 & 29.405 & 14.703 & 14.703 & 114.419 \\
2002 & 120.296 & 38.025 & 19.013 & 19.013 & 115.979 \\
2003 & 116.998 & 37.687 & 18.844 & 18.844 & 118.169 \\
2004 & 110.507 & 34.877 & 17.438 & 17.438 & \\
\hline
\end{tabular}

